\title{
Complex expression patterns support potential roles for maternally derived activins in the establishment of pregnancy in mouse
}

\author{
Rebecca L Jones, Tu'uhevaha J Kaitu'u-Lino, Guiying Nie, L Gabriel Sanchez-Partida', \\ Jock K Findlay and Lois A Salamonsen
}

Prince Henry's Institute of Medical Research and ${ }^{1}$ Monash Institute of Medical Research, Monash Medical Centre, 246 Clayton Road, Clayton, Victoria 3168, Australia

Correspondence should be addressed to $R L$ Jones who is now at Academic Unit of Child Health, Division of Human Development, University of Manchester, St Mary's Hospital Research Floor, Hathersage Road, Manchester M13 0JH, UK; Email:

rebecca.lee.jones@manchester.ac.uk

\begin{abstract}
Maternal-fetal communications are critical for the establishment of pregnancy. Embryonic growth and differentiation factors produced by the oviduct and uterus play essential roles during the pre- and early post-implantation phases. Although several studies indicate roles for activin in embryonic development, gene-knockout studies have failed to identify a critical role in mammalian embryogenesis. We hypothesized that activin is produced by maternal tissues during the establishment of pregnancy, and thus maternally derived activin could compensate for the absence of embryonic activin in null homozygotes during critical developmental stages. We investigated the expression of inhibin $\alpha$, activin $\beta A$, and $\beta B$ subunits in the mouse oviduct and uterus during the estrous cycle and early pregnancy, and in the early conceptus. Inhibin $\alpha$ subunit was weakly expressed, while activin $\beta A$ and $\beta B$ subunits were strongly expressed in oviduct and uterus at estrous, and dramatically upregulated in the uterus on each day of pregnancy between days 3.5 and 8.5 post coitum. Prior to implantation, activin $\beta A$ and $\beta B$ subunits were immunolocalized to oviductal and uterine epithelial cells; following implantation they were expressed in the stroma, in a wave preceding decidualization. Later in pregnancy, activin $\beta A$ and $\beta B$ subunits were present in decidua basalis, trophoblast giant cells, and labyrinth zone of the developing placenta. Expression of activin $\beta$ A subunit was also detected in blastocysts and early postimplantation embryos. These data are consistent with a role for maternally derived activins in the support of the pre-implantation embryo, and during gastrulation and embryogenesis.

Reproduction (2006) 132 799-810
\end{abstract}

\section{Introduction}

Embryo development occurs in a highly specialized maternal environment within the oviduct and uterine lumen during the pre-implantation phases, and subsequently within the uterine implantation site. Cytokines and growth factors secreted by maternal cells support embryo development, as demonstrated by an improved developmental rate when blastocysts are co-cultured in vitro with endometrial and oviductal cells (Seta 2001). Although cytokines, such as granulocyte macrophage colony-stimulating factor and leukemia inhibitor factor, are reported to facilitate mouse embryo development (Robertson \& Seamark 1992, Kauma \& Matt 1995, Tsai et al. 2000), many maternally derived factors remain to be identified. This is critical in order to understand the regulation of early post-implantation embryo development, and improve culture conditions to more closely mimic the maternal environment for embryo culture following in vitro fertilization (IVF).

Activins are potential candidate factors for maternalembryo interactions, due to their roles in regulating cell proliferation, differentiation and apoptosis, and their abundant expression and actions in remodeling tissues. They are abundantly expressed by reproductive tissues, including the uterus, and have been attributed with roles in decidualization, embryogenesis, and organogenesis in a variety of species (Jones et al. 2002).

Activins are dimeric glycoproteins belonging to the transforming growth factor- $\beta$ (TGF- $\beta$ ) superfamily. Activin $A$ is a dimer of $\beta A$ subunits, while activin $B$ is formed from $\beta B$ subunits. These two subunits can also heterodimerize to form activin $A B(\beta A: \beta B)$, or alternatively can dimerize with 
a distinct $\alpha$ subunit to form inhibin $A(\alpha: \beta A)$ or inhibin $B$ $(\alpha: \beta B)$. Activins $A$ and $B$ are believed to have similar actions, with differences in specific functions ascribed to distinct spatial and temporal expressions. Inhibins are potent inhibitors of activins, acting as competitive antagonists through activin receptors (Harrison et al. 2005). Activins bind to cell-surface type II receptors, ActRIIA or ActRIIB, which then recruit the type I receptor, ActRIB/Alk-4. This initiates a signaling cascade through serine/threonine kinase activity, and the phosphorylation and nuclear translocation of intracellular Smads.

Studies in both mice and human provide evidence for roles for activins during the establishment of pregnancy. Mouse, bovine, and human embryos express activin receptors during the pre-implantation phase (Lu et al. 1993, Yoshioka et al. 1998, He et al. 1999). Receptor expression (ActRIB/Alk-4, ActRII, and ActRIIB) is maintained in the post-implantation embryo, and during organogenesis, receptors are expressed in a tissuespecific manner (Feijen et al. 1994, Manova et al. 1995, Verschueren et al. 1995, Roberts et al. 1996). Moreover, pre-implantation mouse and human embryos express activin $\beta A$ and $\beta B$ subunits; at the blastocyst stage, they become localized to the inner cell mass (Albano et al. 1993, Lu et al. 1993, He et al. 1999). The expression of activin $\beta$ subunit in the early postimplantation phase is controversial (van den Eijnden-van Raaij et al. 1992, Manova et al. 1995), but strong expression is detected from E8.5 to 10.5 onwards (Feijen et al. 1994, Roberts \& Barth 1994).

Despite the demonstration that activin A is obligatory for mesoderm induction in Xenopus (Smith et al. 1990), gene manipulation studies in the mouse have failed to demonstrate an absolute requirement for activins in mammalian embryogenesis (Vassalli et al. 1994, Matzuk et al. 1995). This discrepancy could be attributed either to compensatory actions of multiple activin $\beta$ subunits or to maternal supply of activins during pregnancy. As activin $\beta A$ null mice die neonatally, it has not been possible to establish whether embryo development is adversely affected by the absence of maternal activin. In support of the latter, in vitro studies with mouse and bovine embryos indicate that exogenous activin $A$ promotes morula and blastocyst development (Orimo et al. 1996, Yoshioka et al. 1998, Mtango et al. 2003).

In humans, activin $\beta A$ and $\beta B$ subunits are abundantly expressed by uterine epithelial glands and decidual cells during the peri-implantation phase and in early pregnancy (Leung et al. 1998, Otani et al. 1998, Jones et al. 2000). Furthermore, activin A is secreted into the uterine fluid that supports pre-implantation development (Petraglia et al. 1998). Throughout the first trimester of pregnancy, endometrial glandular products, including activin A, are secreted into the intervillous space and thus have sustained roles in supporting embryonic and placental development (Hempstock et al. 2004). Throughout pregnancy, inhibin and activin subunits are also abundantly produced by the placenta, and have been implicated in the regulation of placental development and hormone production (Petraglia et al. 1989, Caniggia et al. 1997).

Expression of activin $\beta A$ subunits by the decidua in rat and mouse in the early post-implantation phase has been reported (Manova et al. 1992, Feijen et al. 1994, Gu \& Gibori 1995). However, maternal production of inhibin/ activin subunits during the pre-implantation phase, and in the implantation site in the mouse, has not been characterized, leaving major gaps in our understanding of potential maternal-embryo communication through the activin system. We hypothesize that maternally derived activins play critical roles in promoting preand early post-implantation embryo development, and subsequently in the differentiation events and tissue remodeling during uterine decidualization and placentation.

We report here the expression and production of inhibin $\alpha, \beta \mathrm{A}$, and $\beta \mathrm{B}$ in the uterus across the mouse estrous cycle and during the establishment of pregnancy. Spatial/temporal expression, and relative abundance of $\beta A$ and $\beta B$ subunits were examined to indicate whether there are overlapping or distinct functions. These data provide evidence consistent with a potential role for maternally derived activin during embryo development/implantation, and verify that the mouse would be a suitable model for functional studies to provide a greater understanding of activin involvement in human implantation.

\section{Materials and Methods}

\section{Animals}

Non-pregnant and pregnant Swiss White out-bred mice (Mus muscularus) were used (Animal Services, Monash University). Mice were housed and handled according to the Monash University animal ethics guidelines on the care and use of laboratory animals. Experimental procedures were approved by the Monash University Animal Ethics Committee (Commitee B, Monash Medical Centre, Melbourne, Australia) for animal experimentation and conducted in accordance with the Australian National Health and Medical Research Council (NHMRC) guidelines.

The stage of the estrous cycle of non-pregnant mice (8-10 weeks, weight 20-22 g) was determined by analysis of vaginal smears. Stage of cycle was determined by the characteristic presence or absence of inflammatory leukocytes, and the histological appearance of epithelial cells. Mice were killed by $\mathrm{CO}_{2}$ asphyxiation and cervical dislocation during the proestrous, estrous, metestrous, and diestrous phases $(n=$ $2 /$ stage), and oviducts and uteri dissected. Ovaries were collected from randomly cycling mice to use as positive controls. 
Female mice (8-10 weeks, weight 20-22 g) were mated with male mice, and checked for vaginal plugs at $0900 \mathrm{~h}$ the following morning. Mice were killed on days $3.5,4.5,5.5,6.5,8.5,10.5$, and 12.5 post coitum (pc); where day 0 is morning of vaginal plug and uteri dissected ( $n=2 /$ day of pregnancy). On day 3.5 pc, ovaries were examined for corpora lutea to confirm ovulation. On day $4.5 \mathrm{pc}$, implantation sites were identified by tail vein injection of Chicago blue dye ( $1 \%$ in saline, $0.1 \mathrm{ml} /$ mouse), $5 \mathrm{~min}$ before killing. Uterine tissues were dissected out immediately and processed for immunohistochemistry and RNA extraction. Implantation and inter-implantation sites were collected separately on days 4.5-6.5 of pregnancy; thereafter only implantation sites were collected. On day 10.5 , the implantation site was dissected to separate the embryo from the implantation site.

Samples were divided into two portions: for immunohistochemistry, tissues were immersion fixed in formalin overnight at $4{ }^{\circ} \mathrm{C}$, prior to thorough washing in Trisbuffered saline (TBS, pH 7.6) and paraffin embedding; the remaining samples were snap-frozen for subsequent RNA extraction.

\section{In vitro fertilization and embryo culture}

\section{Oocytes}

Six-week-old females were superovulated by an i.p. injection of $10 \mathrm{IU}$ equine chorionic gonadotropin (Folligon, Intervet International, Boxmeer, The Netherlands) followed by $10 \mathrm{IU}$ hCG (Chorulon, Intervet International, The Netherlands) in $0.2 \mathrm{ml}$ saline $50 \mathrm{~h}$ later. At 13-14 h after hCG injection, oocyte-cumulus complexes were collected from the oviducts by incubation for $5 \mathrm{~min}$ in HEPES-KSOMaa (Biggers et al. 2000; BDH Chemicals Pty., Ltd, Melbourne, Victoria, Australia) containing $60 \mathrm{IU} / \mathrm{ml}$ hyaluronidase (Sigma type IV-S; Sigma Chemicals Co.). Adhering cumulus cells were removed from oocytes by gentle pipetting and washed in HEPES-KSOMaa. Oocytes were then placed into $20 \mu \mathrm{l}$ drops of modified KSOMaa previously equilibrated under mineral oil in $5 \% \mathrm{CO}_{2}$ in air at $37^{\circ} \mathrm{C}$. Oocytes were incubated for $1 \mathrm{~h}$ at $37^{\circ} \mathrm{C}$ in $5 \%$ $\mathrm{CO}_{2}$ in air before they were used for IVF.

\section{Sperm}

Sperm were collected from 10- to 12-week-old males. Briefly, both the caudae epididymides were dissected from the mice and a small slit was made in each cauda before transfer to $2 \mathrm{ml}$ modified Tyrode's medium (Fraser 1984; $\mathrm{BDH}$ ) and equilibrated in $5 \% \mathrm{CO}_{2}$ in air at $37^{\circ} \mathrm{C}$ in a $35 \mathrm{~mm}$ culture dish (NUNC, Roskilde, Denmark) under oil. The tissue was then removed from the dish $1 \mathrm{~h}$ later, and the sperm concentration was examined and adjusted to $3-5 \times 10^{6} \mathrm{sperm} / \mathrm{ml}$. Sperm were capacitated for a total of $2 \mathrm{~h}$ before IVF.

\section{In vitro fertilization (IVF)}

For IVF, cumulus-free oocytes (30-50) were incubated for $5 \mathrm{~h}$, under mineral oil, in $2 \mathrm{ml}$ capacitated sperm solution $\left(3-5 \times 10^{6} \mathrm{sperm} / \mathrm{ml}\right)$. Oocytes were removed from the sperm solution after $5 \mathrm{~h}$, washed in HEPESKSOMaa, and cultured at $37^{\circ} \mathrm{C}$ in modified KSOMaa under mineral oil in $5 \% \mathrm{CO}_{2}$ in air. Six hours later, oocytes were examined for signs of normal fertilization. Oocytes with two pronuclei and a second polar body were regarded as fertilized. These oocytes were separated from unfertilized oocytes and cultured in modified KSOMaa at $37{ }^{\circ} \mathrm{C}$ under $5 \% \mathrm{CO}_{2}$ in air up to $96 \mathrm{~h}$ for development to the blastocyst stage in vitro. Two and four cell embryos, morulae, and blastocysts (unhatched; $n=3 /$ stage) were collected after $24,48,56-60$, and $72 \mathrm{~h}$ culture respectively, placed directly into $100 \mu \mathrm{I}$ TRIZOL reagent (Invitrogen, Mt Waverly, Victoria, Australia). Samples were then snap-frozen prior to RNA extraction.

\section{RNA extraction and purification}

Total RNA was extracted from frozen uterine samples by acid guanidinium thiocyanate-phenol-chloroform extraction (GTC; Sigma) as previously described (Nie et al. 2000), followed by purification through RNAeasy spin columns (Qiagen) according to the manufacturer's instructions. RNA was extracted from oviducts using RNAeasy spin columns. RNA samples were treated with RNAse-free DNase I (Ambion, Austin, Texas, USA) to remove genomic DNA contamination, and analyzed by spectrophotometry to determine RNA concentration, yield, and purity. RNA concentrations were also analyzed by Ribogreen fluorescence RNA assay (Invitrogen) as previously described (Jones et al. 2004).

RNA was isolated from embryos frozen in TRIZOL using a modified protocol. Samples were allowed to thaw and incubated at room temperature for $30 \mathrm{~min}$, followed by vortexing. Thereafter, the manufacturer's instructions were followed, with the exception of the inclusion of a second chloroform - only extraction to prevent phenol carryover. RNA samples were resuspended in $12 \mu$ diethylpyrocarbonate (DEPC) $\mathrm{H}_{2} \mathrm{O}$, and the entire volume was utilized for RT.

\section{Real-time RT-PCR}

\section{Reverse transcription and validation}

Total RNA $(1 \mu \mathrm{g})$ was reverse transcribed in triplicate reactions using random hexameric primers and AMV-RTase (Roche), at $46{ }^{\circ} \mathrm{C}$ for $90 \mathrm{~min}$. Omission of reverse transcriptase served as a negative control. Triplicate RTs were analyzed for efficiency and reproducibility of the RT reaction by real-time PCR for ribosomal $18 \mathrm{~S}$ subunit using a Light Cycler (Roche) as previously described (Jones et al. 2004). Primers used were: sense $5^{\prime}$-CGG CTA CCA CAT 
CCA AGG AA- $3^{\prime}$ and antisense 5'-GCT GGA ATT ACC GCG GCT-3' ${ }^{\prime}$. Amplified DNA quantitation was performed using SYBR Green I, by comparison with serially diluted cDNA standards, generated by PCR as previously described (Jones et al. 2004). Cycle conditions were as follows: $95^{\circ} \mathrm{C}$ for $10 \mathrm{~min}, 35$ cycles of $95^{\circ} \mathrm{C}$ for $15 \mathrm{~s}, 60^{\circ} \mathrm{C}$ for $5 \mathrm{~s}$, and $72{ }^{\circ} \mathrm{C}$ for $10 \mathrm{~s} .18 \mathrm{~S}$ concentrations $(\mathrm{pg} / \mu \mathrm{l})$ were compared between triplicates and the intra-assay variability of the RT and PCR steps was evaluated. Within triplicates, samples outside $15 \%$ variability of the average 18 concentration were excluded as outliers. Otherwise, triplicates were pooled, creating cDNA reaction products that are close representations of the initial mRNA population. Negative controls were performed by omission of RT. All PCR products were DNA sequenced to confirm identity.

\section{Real-time PCR for inhibin/activin subunits}

Pooled RT samples (diluted in the ratio of $1: 10$ ) were amplified in a Light Cycler for inhibin/activin subunits, using primers: inhibin $\alpha$ : $5^{\prime}$-GCC TTG GCC TTG GTC TCC TGC G-3 $1 / 5^{\prime}$-ACG CGT AGG GAG GTC ATG CTC C-3'; activin $\beta A$ : $5^{\prime}$-GGC TTG AGT GCG ACG GC-3'/ $5^{\prime}$-GCA GCC ACA CTC CTC-3'; activin $\beta B: 5^{\prime}$-TCT TCA TCG ACT TTC GGC TCA T-3'/5'-TGT CAG GCG CAG CCA CAC TCC T-3' (Sigma; Albano et al. 1993). Cycle conditions were as follows: $95^{\circ} \mathrm{C}$ for $10 \mathrm{~min}, 40$ cycles of $95{ }^{\circ} \mathrm{C}$ for $15 \mathrm{~s}, 55 / 62 / 60{ }^{\circ} \mathrm{C}$ for $5 \mathrm{~s}$, and $72{ }^{\circ} \mathrm{C}$ for $15 \mathrm{~s}$. PCRs were run in duplicate or triplicate. Mouse ovarian CDNA, diluted in the ratio of $1: 5$, was included in each run as a positive and quality control.

\section{Immunohistochemistry for inhibin/activin subunits}

Inhibin/activin $\alpha, \beta \mathrm{A}$, and $\beta \mathrm{B}$ subunits were immunolocalized using affinity purified rabbit polyclonal antibodies raised against the individual inhibin subunits (anti-porcine inhibin $\alpha^{1-26}$, anti-porcine inhibin $\beta A^{81-113}$, and antihuman inhibin $\beta B^{80-112}$; kind gift from Prof. Wylie Vale, La Jolla, CA, USA; Vaughan et al. 1989), as previously described (Jones et al. 2000), but with modifications for optimal staining of mouse tissues. Mouse ovary was included as a positive control. In brief, microwave antigen retrieval was performed ( 5 min $\mathrm{HIGH}, 5$ min LOW in a $1 \mathrm{~kW}$ microwave oven, followed by 20-min cooling), and endogenous peroxidase activity blocked with aqueous $\mathrm{H}_{2} \mathrm{O}_{2}$. Primary antibodies were applied at $2 \mu \mathrm{g} / \mathrm{ml}$ in a non-immune block containing $20 \%$ goat serum and $0.1 \%$ Tween-20 in TBS. Negative controls were performed by substitution of primary antibody with $2 \mu \mathrm{g} / \mathrm{ml}$ rabbit IgG (X0936; Dako, Glostrup, Denmark). Antibody binding was thereafter detected by sequential application of conjugate (Dako) for $1 \mathrm{~h}$ at room temperature, with chromogen diaminobenzidine (DAB; Dako), forming an insoluble brown precipitate. Tissue sections were counterstained with Harris's hematoxylin, dehydrated, and mounted with DPX mounting medium (Sigma).

\section{Results}

Expression of inhibin/activin $\alpha, \beta A$, and $\beta B$ subunits in uterus in non-pregnant cycling mice

A positive signal was obtained for all primer pairs for ovarian RT samples included as a positive control in realtime PCRs (data not shown). No amplification product was detected in negative controls. Inhibin $\alpha$ subunit mRNA was almost undetectable in cycling uterine samples (Fig. 1A). In contrast, activin $\beta A$ mRNA was abundantly expressed in non-pregnant uterine samples, with fluctuations across the estrous cycle. mRNA levels were increased greater than threefold from the proestrous to estrous phases, thereafter levels decreased in the metestrous phase (Fig. 1A). A similar pattern was detected for $\beta B$ subunit mRNA (Fig. 1A). Moreover, both activin $\beta$ subunits were expressed by the oviduct, with an identical cyclical expression pattern, and maximal upregulation observed in estrous phase (data not shown).

Immunohistochemistry verified this expression pattern at the protein level and identified the cellular location. Intense immunostaining was detected for $\alpha, \beta A$, and $\beta B$ subunits in ovarian follicles and corpora lutea in agreement with known established patterns reviewed by Findlay (1993) (Fig. $1 \mathrm{~B}$ and $C$ ). $\beta A$ and $\beta B$ subunits immunolocalized to epithelial cells lining the oviduct (Fig. 1D), and in the uterus, to the luminal and glandular epithelium (Fig. 1E-L). Consistent with mRNA expression patterns, endometrial immunostaining levels varied markedly during the estrous cycle. In the proestrous phase, $\beta$ A subunit was present in the luminal epithelium (Fig. 1E). In the estrous phase, immunostaining levels were increased in luminal and glandular epithelial cells (Fig. 1F), and in addition, intensely stained single cells (possibly infiltrating immune cells) were identified in the sub-epithelial zone (Fig. 1G). Following estrous, $\beta \mathrm{A}$ immunostaining was minimal or absent in metestrous (Fig. $1 \mathrm{H}$ ) and diestrous phases (data not shown). $\beta$ B subunit protein expression was low in proestrous endometrium in both the luminal and the glandular epithelium (data not shown), but was elevated in the estrous phase in all epithelial cells (Fig. 1I). No intensely stained stromal cell was detected in the subepithelial zone (Fig. 1J). In metestrous (Fig. 1K) and diestrous (Fig. $1 \mathrm{~L}$ ) endometria, $\beta \mathrm{B}$ immunostaining was severely diminished in luminal epithelial cells, but retained in epithelial glands during both post-estrous phases. Low immunostaining was detected for $\alpha$ subunit in oviduct (Fig. 1B), whereas none was detectable in the uterus (Fig. 1M).

\section{Expression of activin subunits in mouse pre-implan- tation embryos}

Real-time PCR was conducted for activins $\beta A$ and $\beta B$ on embryos at the two cell, four cell, morula, and blastocyst 


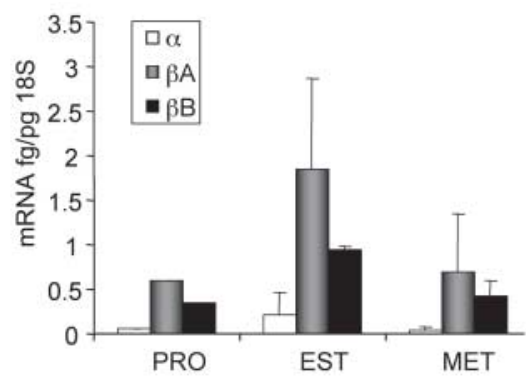

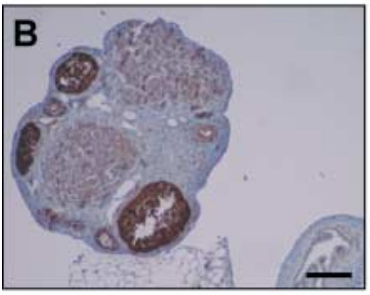
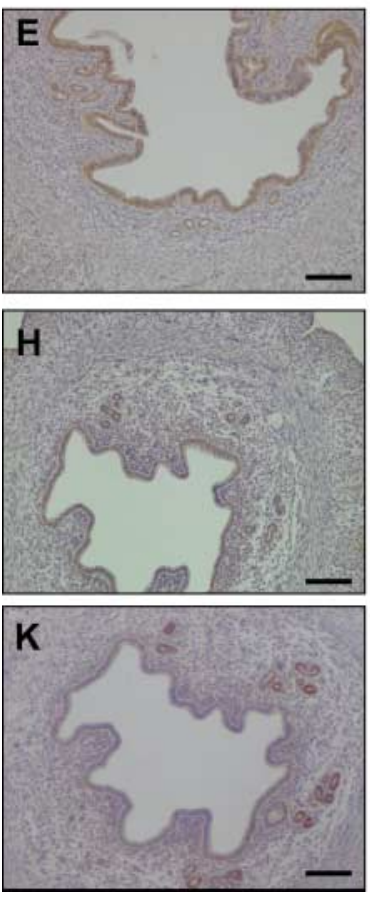
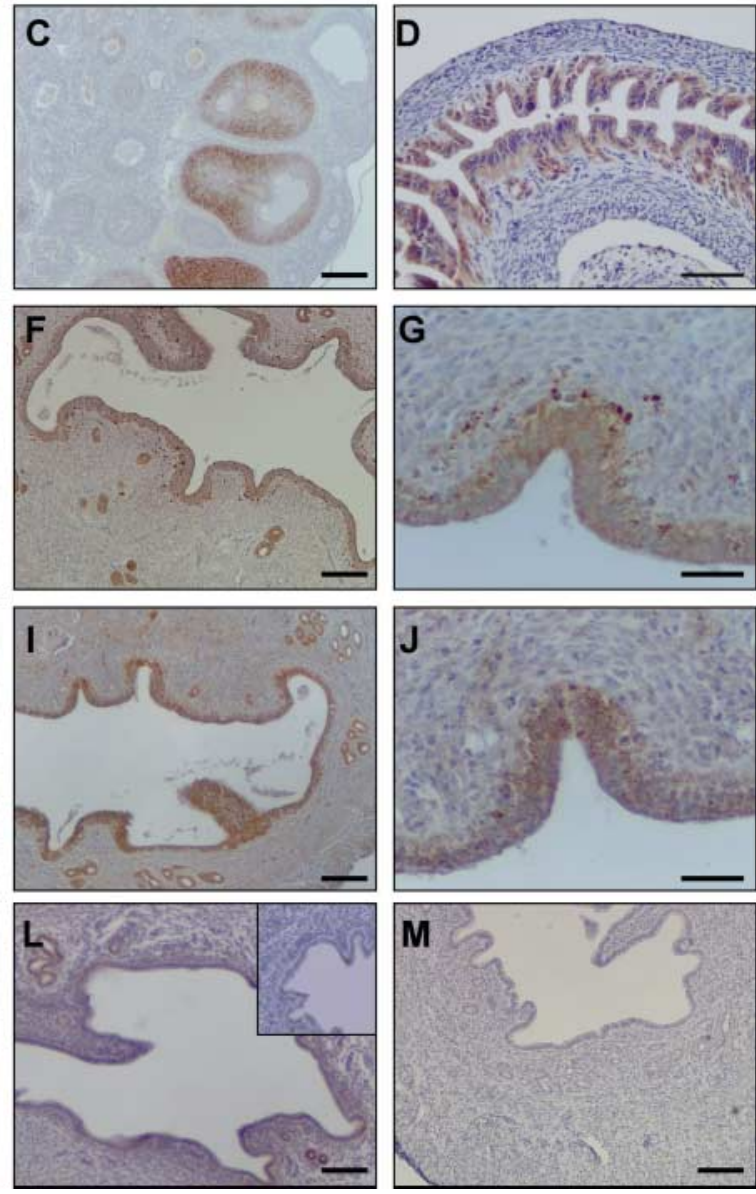
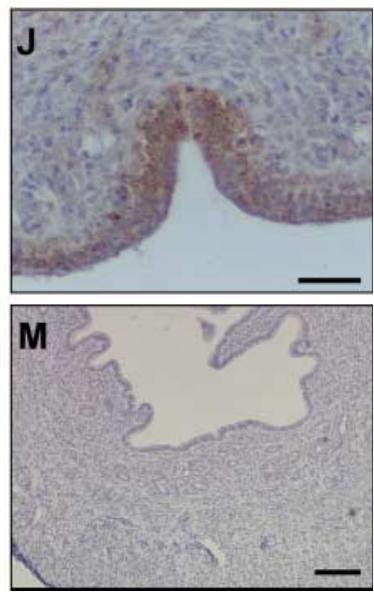

Figure 1 Expression of inhibin, inhibin/activin subunit mRNA, and protein in non-pregnant cycling mouse reproductive tract. (A) mRNA expression of inhibin $\alpha$, activin $\beta A$, and activin $\beta B$ during the proestrous (PRO), estrous (EST), and metestrous (MET) of the estrous cycle of the mouse. Values are the average of two independent observations and error bars show the range. (B)-(M) Immunostaining for inhibi$n$ /activin subunits in non-pregnant female uterus and oviduct. (B) Inhibin $\alpha$ in ovary and oviduct, $(C)$ activin $\beta B$ in ovary, (D) activin $\beta A$ in oviduct, $(\mathrm{E})-(\mathrm{G})$ uterine expression of activin $\beta A$ in (E) proestrous phase, (F) estrous, (G) high magnification of strongly stained subepithelial immune cells in estrous phase. $(\mathrm{H})-(\mathrm{L})$ Uterine expression of activin $\beta B$ in $(\mathrm{H})$ proestrous, (I) estrous, (J) high magnification showing absence of staining in subepithelial immune cells in estrous phase, (K) metestrous, and (L) diestrous phases. Inset is negative control showing no staining. (M) Inhibin $\alpha$ staining was absent in all uteri examined. Scale bar $=100 \mu \mathrm{m}$, except $(B)=200 \mu \mathrm{m}$ and $(\mathrm{D}, \mathrm{G}$ and $\mathrm{J})=50 \mu \mathrm{m}$. (unhatched) stages ( $n=3$ pooled embryo RNA/stage). A positive signal for both activin $\beta A$ and $\beta B$ subunits was detected in ovary included as a positive control (12.8 fg $\beta A$ mRNA/pg 18S, 4.25 fg $\beta$ B mRNA/pg 18S). $\beta A$ mRNA was below the limit of detection in all embryos except for blastocysts (3.5 fg $\beta \mathrm{A} \mathrm{mRNA/pg} \mathrm{18S);} \beta$ B expression was not detectable in embryos, including blastocysts (Fig. 2). $18 \mathrm{~S}$ was used as a control for RNA integrity.

\section{Expression of inhibin/activin $\alpha, \beta A$, and $\beta B$ subunits during establishment of pregnancy}

Inhibin $\alpha$ mRNA was undetectable by real-time PCR in the uterus in the peri-implantation phase (days 3.5-4.5 pc;
Fig. 3A). Very low levels of expression were detected in the implantation site from days 5.5 to 8.5 . In contrast, activin $\beta A$ mRNA was markedly upregulated on day 3.5 pc compared with non-pregnant (NP) uteri (greater than tenfold; Fig. 3B, inset). On the day of embryo attachment (day $4.5 \mathrm{pc}$ ), activin $\beta A$ was increased in one out of two implantation site samples, while no change in mRNA expression was seen in inter-implantation sites. From day 5.5, activin $\beta A$ subunit expression rose further, with expression levels approximately tenfold higher in both implantation and inter-implantation sites compared with day 4.5 (Fig. 3B). Despite considerable variation, reflecting the heterogeneity of this dynamic tissue, a further increase (approximately threefold) in $\beta A$ mRNA 


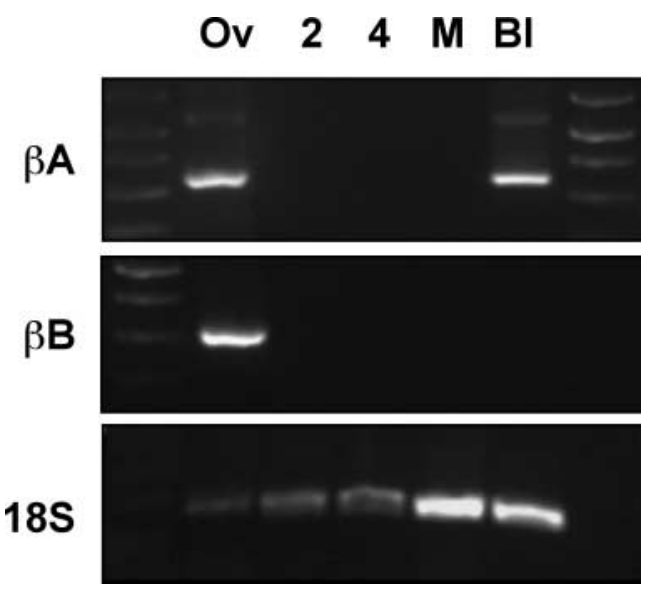

Figure 2 Real-time PCR for $18 \mathrm{~S}$, activin $\beta \mathrm{A}$, and $\beta \mathrm{B}$ in pre-implantation mouse embryos, at the two cell, four cell, morula, and blastocyst stages $(n=3$ embryos/stage). Ovary (Ov) was included as a positive control.

expression was detected on each of the days 6.5 and 8.5 pc in implantation sites, while levels remained static in inter-implantation sites. At day 10.5, expression levels were examined in the uterus and embryo separately. This showed a sharp decline in uterine activin $\beta A$ mRNA expression and low embryonic expression of $\beta$ A subunit.

A similar expression pattern was detected for $\beta B$ mRNA; however, expression levels were consistently 50-100 times lower than $\beta A$ mRNA levels (Fig. 3C). Furthermore, the increase in $\beta B$ subunit expression with the onset of pregnancy was delayed compared with that of $\beta A$, with only a slight increase in activin $\beta B$ mRNA from non-pregnant to day 4.5 (Fig. 3C, inset). However, on day $5.5, \beta B$ mRNA was upregulated more than 30 -fold in implantation sites, and fivefold in inter-implantation sites, compared with day 4.5 (Fig. 3C). Expression increased a further threefold in implantation sites on day 6.5 and thereafter a slight decline was detected on days 8.5-10.5 in the uterine tissues. Activin $\beta B$ mRNA expression was detected in the embryo, but at very low levels compared with activin $\beta A$ mRNA expression.

\section{Immunohistochemistry for inhibin/activin subunits}

Consistent with mRNA expression patterns, $\beta$ A protein was upregulated on day 3.5 of pregnancy, in luminal and glandular epithelium (Fig. 4A) and also in the stromal zone underlying the luminal epithelium, particularly in the anti-mesometrial region. With blastocyst attachment on day 4.5, stromal immunostaining became more intense and polarized at the anti-mesometrial zone, where the primary decidual response occurs (Fig. 4B and C). Immunostaining for $\beta \mathrm{A}$ was downregulated in the luminal epithelium in implantation site compared with NP. A distinct staining pattern was observed throughout inter-implantation sites, with intense immunostaining in
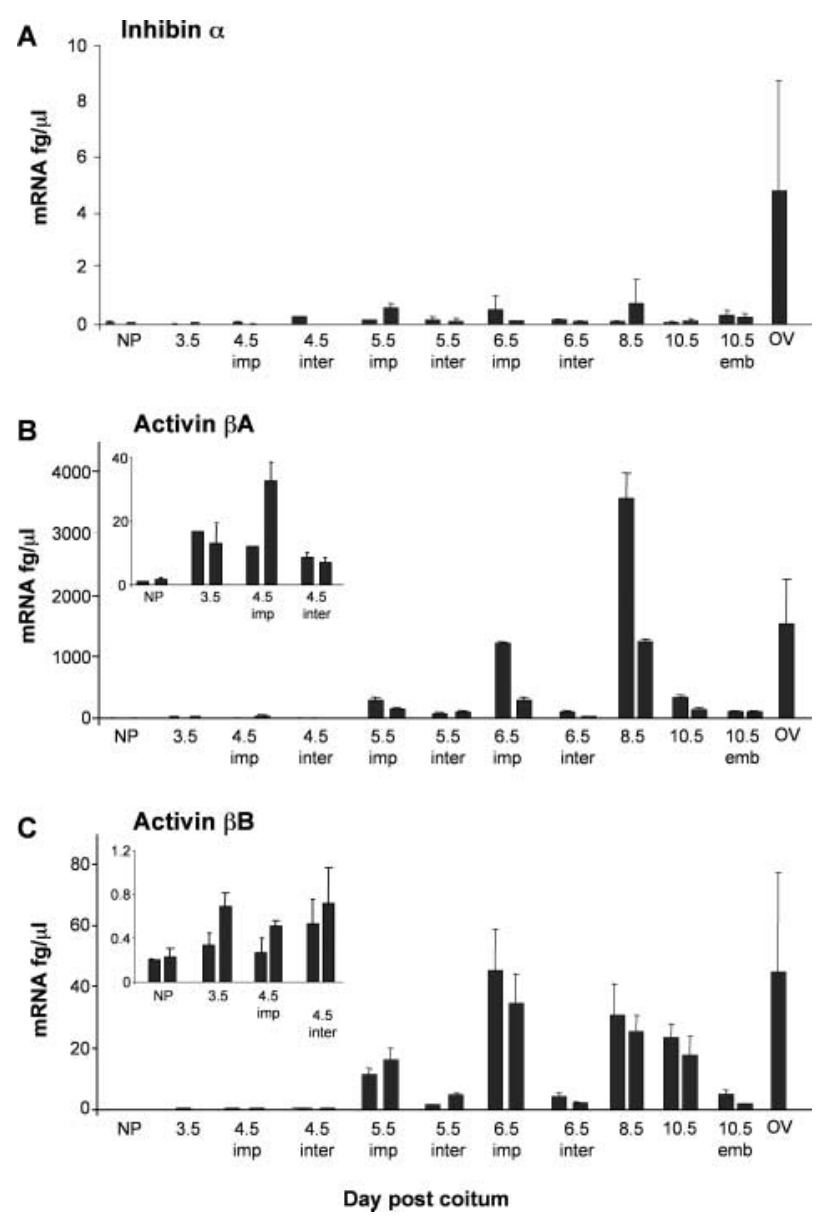

Figure 3 Quantitation of $(A)$ inhibin $\alpha,(B)$ activin $\beta A,(C)$ activin $\beta B$ subunit mRNA expressions in mouse uterus during the establishment of pregnancy. Day post coitum is shown on the $x$-axis. NP, non-pregnant; imp, implantation site; inter, inter-implantation site; emb, embryo; OV, ovary. For (B) and (C), NP-day 4.5 is magnified in inset, due to the differences in scale. Data are the mean expression ( \pm s.D.) from triplicate PCR runs, for two individual mice at each time point.

epithelial glands, while luminal epithelium and stroma possessed minimal immunoreactivity (Fig. 4D). By day 5.5 pc, activin $\beta$ A expression exhibited a 'butterfly-like' pattern, with intense immunoreactivity in the antimesometrial and mesometrial zones distant to the implanting embryo, and with stroma immediately surrounding the embryo devoid of immunostaining (Fig. 4E and F). Basal epithelial glands maintained strong activin $\beta$ A expression (Fig. 4E). Between days 6.5 and 8.5 pc, uterine immunoreactivity for activin $\beta A$ diminished and became limited to the basal zone (bz) adjacent to the myometrium (Fig. 4G and J). From day 5.5 onwards, intense immunostaining for activin $\beta A$ was observed in and surrounding the developing embryonic and extraembryonic structures (Fig. 4F, $\mathrm{H}$ and I).

An almost identical pattern of activin $\beta B$ was observed in the implantation site (Fig. 5). Intense staining was detected in epithelial glands throughout early pregnancy 

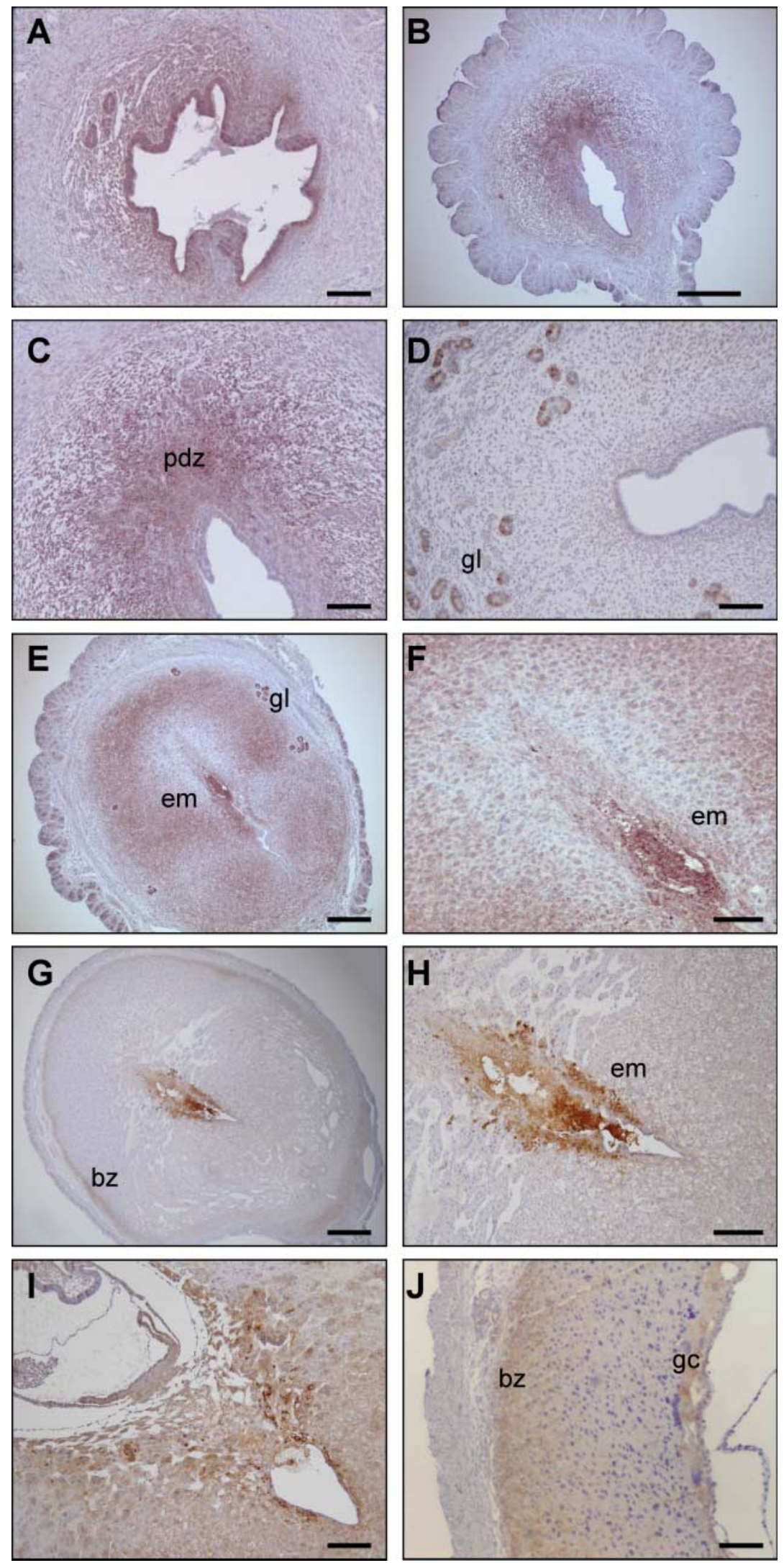

Figure 4 Immunohistochemical localization of activin $\beta A$ in mouse uterus during early pregnancy. Photomicrographs are orientated such that the mesometrium is at the lower right-hand side in each case. (A) Day 3.5 post coitum (pc), (B) and (C) day 4.5 showing blastocyst (collapsed) attachment to the anti-mesometrial pole and activin $\beta A$ staining in the primary decidual zone (pdz), (D) day 5.5 pc inter-implantation, and (E) day 5.5 pc implantation site, showing staining in the embryo (em) and epithelial glands (gl), (F) high magnification of embryo at day 5.5 pc, (G) day 6.5 pc implantation site, illustrating the restriction of activin $\beta A$ staining to the embryo and basal zone (bz) of the decidua, $(\mathrm{H})$ high magnification of embryo at day $6.5 \mathrm{pc}$, (I) activin $\beta \mathrm{A}$ immunostaining in the embryo and developing placenta, (J) antimesometrial zone showing staining restricted to the basal zone, and faint staining in giant cells $(\mathrm{gc})$. Scale bars $=100 \mu \mathrm{m}$, except $(B, E, G)=200 \mu \mathrm{m}$ and $(\mathrm{F}, \mathrm{H})=50 \mu \mathrm{m}$ 

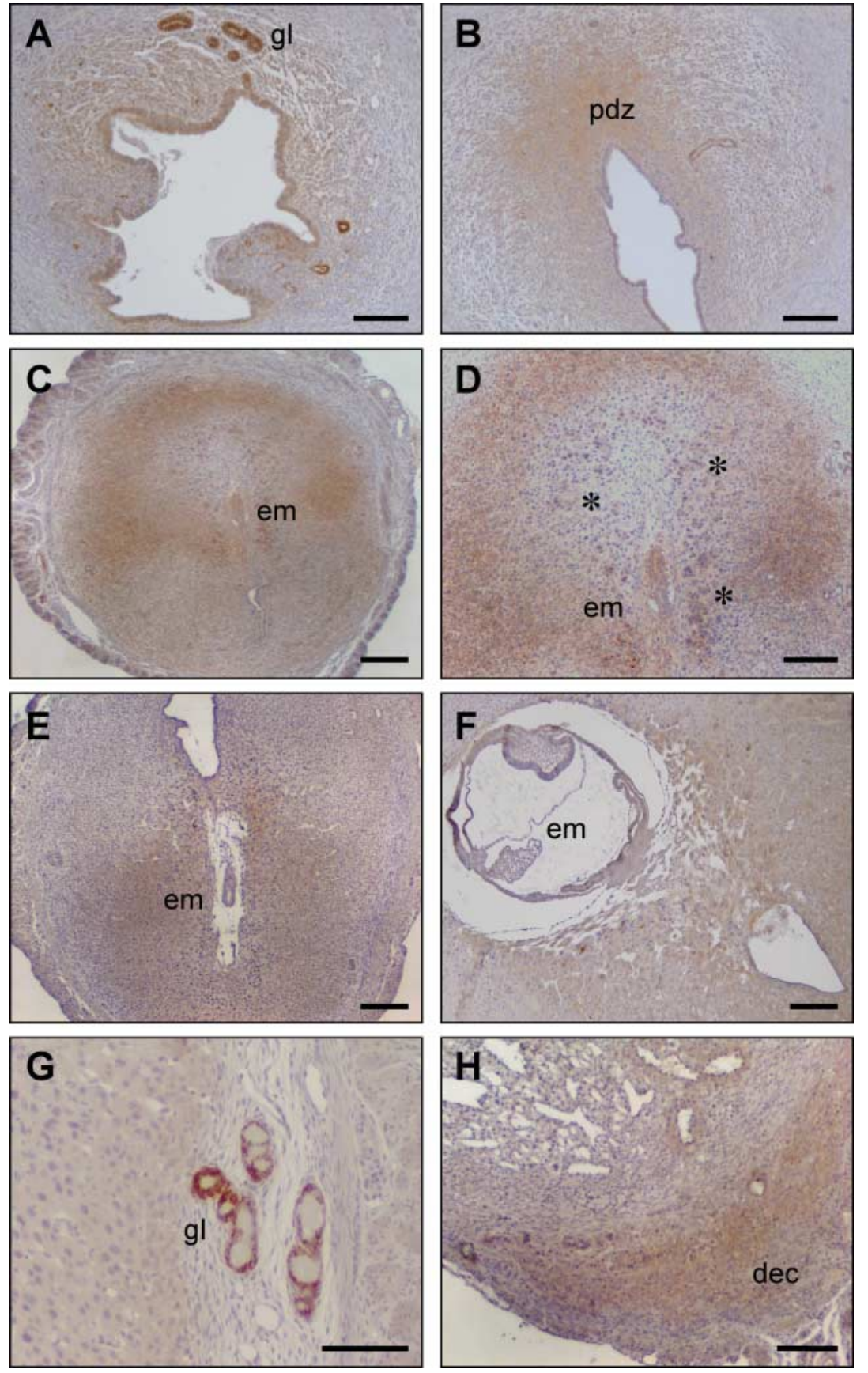

Figure 5 Immunohistochemical localization of activin $\beta B$ in mouse uterus during early pregnancy. Photomicrographs are orientated such that the mesometrium is at the lower right-hand side in each case. (A) Activin $\beta$ B staining on day 3.5 post coitum (pc), primarily in epithelial glands ( $\mathrm{gl}),(\mathrm{B})$ uterus on day 4.5 showing staining in the primary decidual zone (pdz), (C and D) low and high magnification images of $\beta B$ in day $5.5 \mathrm{pc}$ implantation site, showing staining in the embryo (em) and in maternal cells surrounding the embryo, (E) day 6.5 pc, and (F) day 8.5 pc implantation sites, illustrating faint staining for $\beta B$ subunit in the mesometrial decidua, but with no staining generally absent in the embryo, $(\mathrm{G})$ intense immunostaining in epithelial glands in the basal zone on day $8.5 \mathrm{pc},(\mathrm{H}) \beta \mathrm{B}$ immunostaining becomes focused to the decidua basalis on day 9.5 pc. Scale bars $=100 \mu \mathrm{m}$, except $(\mathrm{C}$ and $\mathrm{E})=$ $200 \mu \mathrm{m}$, and $(\mathrm{D}$ and $\mathrm{G})=50 \mu \mathrm{m}$. (e.g., Fig. $5 \mathrm{~A}$ and $\mathrm{G}$ ). Activin $\beta \mathrm{B}$ immunostaining was faint or absent in the embryo in the early postimplantation phases (Fig. 5C-F), but it intensely immunolocalized to individual maternal cells surrounding the implanting embryo on day 5.5 (Fig. 5D), and was generally present in the mesometrial zone surrounding the developing extra-embryonic structures on days 6.68.5 (Fig. 5E and F).

From days 8.5 to $12.5 \mathrm{pc}$, strong staining for activin $\beta \mathrm{A}$ (Fig. $6 \mathrm{~A}$ ) and $\beta \mathrm{B}$ (Figs $5 \mathrm{H}$ and $6 \mathrm{C}$ ) subunits was detected in the mesometrial decidua basalis, localized specifically to decidual cells, while uNK cells were unstained (Fig. 6B). During this time, immunoreactivity for activin subunits was also detected in the developing placenta. Inhibin $\alpha$ immunostaining was faint or absent in the developing placenta (Fig. 6D). Immunostaining for both activin subunits was present in enlarged giant cells (Fig. 6E) and in the trophoblast cells of the labyrinth zone (Fig. 6A and F). Activin $\beta A$ was absent from the spongiotrophoblast layer (Fig. 6A and G), 
while $\beta \mathrm{B}$ immunostaining was present, but at reduced levels compared with decidua and labyrinth (Fig. 6C and $\mathrm{H})$. Of interest was the intense staining for $\beta B$ in the cells lining the large maternal vessels of the spongiotrophoblast layer (Fig. 6H).

\section{Discussion}

Activin $\beta A$ and $\beta B$ subunits were found to be strongly expressed in the mouse female reproductive tract during the estrous cycle and establishment of pregnancy. In nonpregnant cycling mice, activin $\beta$ subunit mRNA, and
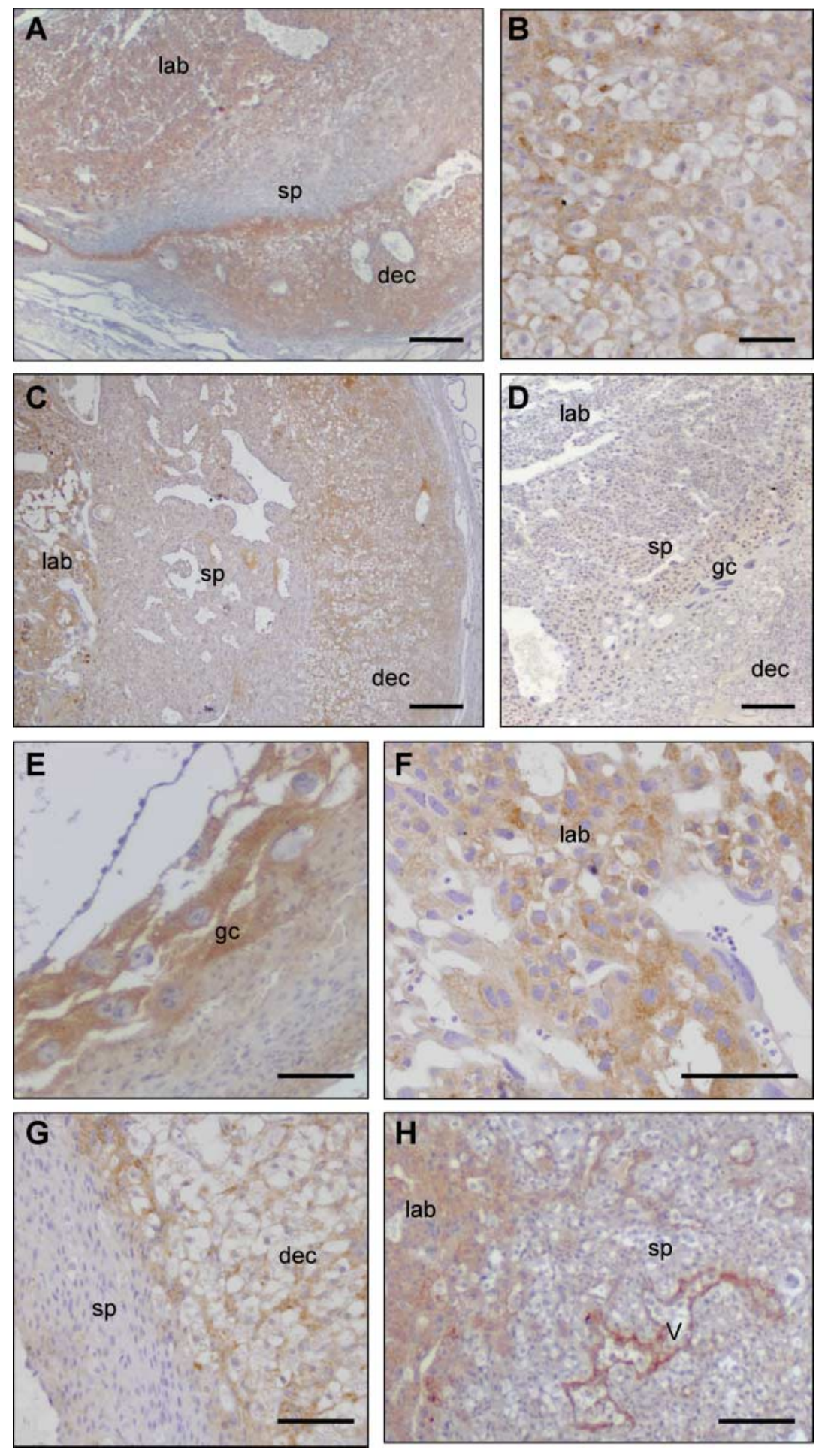

Figure 6 Immunohistochemical localization of inhibin/activin subunits in mouse placenta on day 12.5 post coitum (pc). (A) Activin $\beta A$ immunoreactivity is intense in labyrinth (lab) and decidua basalis (dec), but faint or absent in spongiotrophoblast (sp), (B) high magnification images of $\beta$ A decidual cells, (C) activin $\beta B$ positively immunostained labyrinth, spongiotrophoblast, and decidua, while (D) inhibin $\alpha$ immunostaining was absent from all placental layers, (E) activin $\beta A$ staining in trophoblast giant cells, and $(F)$ activin $\beta B$ staining in placental labyrinth, $(\mathrm{G})$ activin $\beta \mathrm{A}$ is absent from spongiotrophoblast, while $(\mathrm{H})$ activin $\beta \mathrm{B}$ is present around blood vessels $(v)$ in the spongiotrophoblast. Scale bars on $(A, C$ and $D)=200 \mu \mathrm{m}$, on $(H)=100 \mu \mathrm{m}$, and on $(B, E-G)=50 \mu \mathrm{m}$. 
protein expression levels fluctuated in a cycle-dependent manner in the uterus. During early pregnancy, both activin $\beta$ subunits were strikingly upregulated in uterine tissues, and embryonic activin $\beta A$ mRNA expression was detectable from the blastocyst stage. Immunohistochemical studies localized activin $\beta A$ and $\beta B$ subunits to the uterine epithelial and decidual cells, as well as to the developing embryo and placenta.

The predominant source of activin $\beta$ subunits during the estrous cycle and pre-implantation phase were the epithelial cells lining the oviduct and endometrium. The strong expression of activin subunits by the oviductal epithelial cells is consistent with findings by Lu et al. (1993) and with a role for maternally derived activins, secreted into oviductal fluid, in facilitating pre-implantation embryo development. Both $\beta A$ and $\beta B$ subunits mRNA and protein were elevated at estrus, suggesting positive regulation by estrogen, and a 'priming' of the oviduct and uterus in anticipation of pregnancy. A further increase in activin $\beta A$ expression occurred in the uterus on day 3.5, corresponding to the entry of morulae into the uterine lumen and the first embryonic differentiation steps of morula compaction and blastocyst development, hatching and implantation.

The elevation in maternally derived activin correlating these critical steps is consistent with an involvement for activin in facilitating embryonic development. Furthermore, embryonic expression of activin $\beta A$ mRNA becomes detectable with blastocyst development. ActRs are expressed by the embryo during this period, and in the human, expression levels of both type I and II receptors increase with blastocyst formation (He et al. 1999). Indeed, treatment of mouse and bovine embryos with activin $\mathrm{A}$ in vitro accelerates morula and blastocyst development, blastocyst hatching, and increases blastocyst cell number (Orimo et al. 1996, Yoshioka et al. 1998, Mtango et al. 2003); while neutralization of endogenous activin with follistatin treatment in vitro significantly retards embryonic development (Yoshioka et al. 1998). Although activin action is not obligatory for pre-implantation development, as embryos lacking ActRs survive beyond the blastocyst stage $(\mathrm{Gu}$ et al. 1998, Song et al. 1999), it is likely that the deficit of maternal growth factors is responsible for the retarded development observed during embryo culture (Seta 2001). Therefore, the corroboration between the previous in vitro data and the specific temporal expression patterns for activin subunits in oviductal and uterine epithelia, support the hypothesis that activins contribute to the maternal support of pre-implantation embryo development.

The upregulation of activin $\beta A$ and $\beta B$ subunit expressions in the implantation site in early pregnancy is primarily due to expression by the developing decidua, and later, by the placental cells. Activin $\beta A$ expression has been well characterized during decidualization in the rat (Gu et al. 1995), and here we demonstrate a similar expression pattern for both $\beta A$ and $\beta B$ in the mouse decidua. Importantly, the upregulation of activin subunits in stromal cells precedes decidualization, with a coordinated wave of up- and downregulation spreading through the uterus in advance of the onset and spread of decidualization. This indicates a preparative role for activin prior to decidual differentiation. In human endometrial stromal cells, activin upregulates matrix metalloproteinases (MMPs; Jones et al. 2006), which have critical actions during decidualization, at least in the rat (Alexander et al. 1996, Rechtman et al. 1999). Interestingly, in the rodent uterus, MMP-2 and -3 have almost identical expression patterns to that of activin during early pregnancy (Alexander et al. 1996, Bany et al. 2000), suggesting an interaction between activins and MMPs during decidualization in the mouse. Later in pregnancy, activin promotes decidual apoptotic regression in the rat, allowing expansion of the implantation site for placentation and embryonic growth (Gu et al. 1995, Tessier et al. 2003). Interestingly, the primary decidual cells adjacent to the embryo on day 7.5 that stain intensely for activin subunits correspond to the site of maximum apoptosis (Alexander et al. 1996).

In the developing placenta, activin $\beta$ subunit expression was evident in the invasive trophoblast giant cells at the maternal-fetal interface, possibly related with a role in promoting trophoblast invasion, as has been demonstrated in the human (Caniggia et al. 1997). In the placenta at day 12.5 , activin $\beta A$ and $\beta B$ subunits were clearly localized predominantly to the syncytiotrophoblast of the labyrinth. This is identical with the spatial expression of activin/inhibin subunits in the villous syncytiotrophoblast of the human placenta (Lockwood et al. 1997); their expression is apparent immediately with the onset of syncytialization both in vivo and in vitro (Debieve et al. 2000, Jones et al. 2006).

The significance of multiple activin $\beta$ subunits is not known. $\beta A$ and $\beta B$ subunits frequently exhibit distinct expression patterns, suggesting specific functions. For example, in developing embryos, widespread expression of $\beta A$ in mesenchymally derived tissues, including gonads and brain, has been reported (Manova et al. 1992); while $\beta B$ expression is primarily limited to reproductive tissues. However, in the uterus, $\beta A$ and $\beta B$ have almost identical expression patterns, but $\beta B$ mRNA is consistently far less abundant than $\beta$ A. This may explain the failure of previous studies to detect $\beta B$ subunit in uterine and embryonic tissues using less sensitive methods (Manova et al. 1992). Female mice lacking activin $\beta B$ subunit undergo normal implantation and early pregnancy, but experience perinatal loss of progeny, suggesting maternal activin B fulfils critical functions late in pregnancy (Vassalli et al. 1994). Fertility cannot be assessed in the $\beta$ A knockout, due to neonatal lethality (Matzuk etal. 1995). However, when the $\beta B$ subunit was 'knocked-in' into the $\beta A$ gene locus of the $\beta A$-null mutant, the female mice reproduced, but 
exhibited a severely decreased pregnancy rate (Brown et al. 2000). The uterine activin $\beta A$ subunit deficiency contribution to reduced fertility has not been established. However, these gene manipulation models suggest distinct functions for $\beta A$ and $\beta B$ in the female reproductive system.

The present study provides evidence for the uterine epithelial (glandular) and decidual cells as a significant source of activin in the mouse at the time of implantation and early embryonic development, the uterine epithelial (glandular) and decidual cells are a significant source of activin in the mouse. Therefore, during gastrulation, when activin action is obligatory in Xenopus, lack of embryonic $\beta \mathrm{A}$ and $\beta \mathrm{B}$ could be compensated for by the abundant maternal contribution, giving a plausible explanation for the absence of gastrulation-related defects in the activin $\beta \mathrm{A}$ null $(-/-)$ embryos (in activin $\beta A$ subunit heterozygote $(+/-)$ mothers). This is supported by the absolute requirement for activin signaling for mesoderm induction in mice, with arrested development prior to gastrulation observed in activin receptor knockout mice (Alk-4, and double ActRII/ActRIIB nulls; Gu et al. 1998, Song et al. 1999). The results of the present study strongly support the hypothesis that maternally derived activin fulfils a critical role in early embryonic development in the mouse.

In summary, we have characterized in detail the spatial and temporal expression patterns of inhibin/activin $\alpha, \beta A$, and $\beta B$ subunits during the establishment of pregnancy in the mouse. We demonstrate that maternally derived activin subunits, predominantly $\beta \mathrm{A}$, are specifically upregulated in the uterine luminal epithelium during pre-implantation embryo development, and subsequently in the decidua of the implantation site, during the critical development events of gastrulation and organogenesis. These data suggest that activins secreted by the oviduct and uterus could facilitate the development of the embryo prior to implantation. Furthermore, our findings support the hypothesis that maternally derived activins play important roles in early post-implantation embryo development. The observed expression patterns in the mouse uterus bear marked resemblance to those in the human uterus during the preparation for implantation and in early pregnancy, thus suggesting it to be a suitable model to delineate the functional roles for activins in maternal-fetal interactions during the establishment of pregnancy.

\section{Acknowledgements}

We acknowledge the technical assistance of Natalie Hannan and Ying Li. Studies were funded by NH\&MRC Program Grant (\#241000). RLJ was the recipient of the Ella McKnight Scholarship (Royal Australian and New Zealand College of Obstetrics \& Gynaecology). LAS and JFK are supported by fellowships \#143798 and 198705 respectively from NH\&MRC. The authors declare that there is no conflict of interest that would prejudice the impartiality of this scientific work.

\section{References}

Albano RM, Groome N \& Smith JC 1993 Activins are expressed in preimplantation mouse embryos and in ES and EC cells and are regulated on their differentiation. Development 117 711-723.

Alexander CM, Hansell EJ, Behrendtsen O, Flannery ML, Kishnani NS, Hawkes SP \& Werb Z 1996 Expression and function of matrix metalloproteinases and their inhibitors at the maternal-embryonic boundary during mouse embryo implantation. Development 122 1723-1736.

Bany BM, Harvey MB \& Schultz GA 2000 Expression of matrix metalloproteinases 2 and 9 in the mouse uterus during implantation and oil-induced decidualization. Journal of Reproduction and Fertility 120 125-134.

Biggers JD, McGinnis LK \& Raffin M 2000 Amino acids and preimplantation development of the mouse in protein-free potassium simplex optimized medium. Biology of Reproduction $\mathbf{6 3}$ 281-293.

Brown CW, Houston-Hawkins DE, Woodruff TK \& Matzuk MM 2000 Insertion of Inhbb into the Inhba locus rescues the Inhba-null phenotype and reveals new activin functions. Nature Genetics $\mathbf{2 5}$ 453-457.

Caniggia I, Lye SJ \& Cross JC 1997 Activin is a local regulator of human cytotrophoblast cell differentiation. Endocrinology 138 3976-3986.

Debieve F, Pampfer S \& Thomas K 2000 Inhibin and activin production and subunit expression in human placental cells cultured in vitro. Molecular Human Reproduction 6 743-749.

Feijen A, Goumans MJ \& van den Eijnden-van Raaij AJ 1994 Expression of activin subunits, activin receptors and follistatin in postimplantation mouse embryos suggests specific developmental functions for different activins. Development 120 3621-3637.

Findlay JK 1993 An update on the roles of inhibin, activin, and follistatin as local regulators of folliculogenesis. Biology of Reproduction 48 15-23.

Fraser LR 1984 Mouse sperm capacitation in vitro involves loss of a surface-associated inhibitory component. Journal of Reproduction and Fertility 72 373-384.

Gu Y \& Gibori G 1995 Isolation, culture, and characterization of the two cell subpopulations forming the rat decidua: differential gene expression for activin, follistatin, and decidual prolactin-related protein. Endocrinology 136 2451-2458.

Gu Y, Srivastava RK, Ou J, Krett NL, Mayo KE \& Gibori G 1995 Cellspecific expression of activin and its two binding proteins in the rat decidua: role of alpha 2-macroglobulin and follistatin. Endocrinology 136 3815-3822.

Gu Z, Nomura M, Simpson BB, Lei H, Feijen A, van den Eijnden-van Raaij J, Donahoe PK \& Li E 1998 The type I activin receptor ActRIB is required for egg cylinder organization and gastrulation in the mouse. Genes \& Development 12 844-857.

Harrison CA, Gray PC, Vale WW \& Robertson DM 2005 Antagonists of activin signaling: mechanisms and potential biological applications. Trends in Endocrinology and Metabolism 1673.

He ZY, Liu HC, Mele CA, Barmat L, Veeck LL, Davis O \& Rosenwaks Z 1999 Expression of inhibin/activin subunits and their receptors and binding proteins in human preimplantation embryos. Journal of Assisted Reproduction and Genetics 16 73-80.

Hempstock J, Cindrova-Davies T, Jauniaux E \& Burton GJ 2004 Endometrial glands as a source of nutrients, growth factors and cytokines during the first trimester of human pregnancy: a morphological and immunohistochemical study. Reproductive Biology and Endocrinology 258.

Jones RL, Salamonsen LA, Critchley HO, Rogers PA, Affandi B \& Findlay JK 2000 Inhibin and activin subunits are differentially expressed in endometrial cells and leukocytes during the menstrual cycle, in early pregnancy and in women using progestin-only contraception. Molecular Human Reproduction 6 1107-1117. 
Jones RL, Salamonsen LA \& Findlay JK 2002 Potential roles for endometrial inhibins, activins and follistatin during human embryo implantation and early pregnancy. Trends in Endocrinology and Metabolism 13 144-150.

Jones RL, Hannan NJ, Kaitu'u TJ, Zhang J \& Salamonsen LA 2004 Identification of chemokines important for leukocyte recruitment to the human endometrium at the times of embryo implantation and menstruation. Journal of Clinical Endocrinology and Metabolism 89 6155-6167.

Jones RL, Findlay JK, Farnworth PG, Robertson DM, Wallace E \& Salamonsen LA 2006 Activin A and inhibin a differentially regulate human uterine matrix metalloproteinases: potential interactions during decidualization and trophoblast invasion. Endocrinology 147 724-732.

Kauma SW \& Matt DW 1995 Coculture cells that express leukemia inhibitory factor (LIF) enhance mouse blastocyst development in vitro. Journal of Assisted Reproduction and Genetics 12 153-156.

Leung PH, Salamonsen LA \& Findlay JK 1998 Immunolocalization of inhibin and activin subunits in human endometrium across the menstrual cycle. Human Reproduction 13 3469-3477.

Lockwood GM, Ledger WL, Barlow DH, Groome NP \& Muttukrishna S 1997 Measurement of inhibin and activin in early human pregnancy: demonstration of fetoplacental origin and role in prediction of earlypregnancy outcome. Biology of Reproduction 57 1490-1494.

Lu RZ, Matsuyama S, Nishihara M \& Takahashi M 1993 Developmental expression of activin/inhibin beta $A$, beta $B$, and alpha subunits, and activin receptor-IIB genes in preimplantation mouse embryos. Biology of Reproduction 49 1163-1169.

Manova K, Paynton BV \& Bachvarova RF 1992 Expression of activins and TGF beta 1 and beta 2 RNAs in early postimplantation mouse embryos and uterine decidua. Mechanisms of Development 36 141-152.

Manova K, De Leon V, Angeles M, Kalantry S, Giarre M, Attisano L, Wrana J \& Bachvarova RF 1995 mRNAs for activin receptors II and IIB are expressed in mouse oocytes and in the epiblast of pregastrula and gastrula stage mouse embryos. Mechanisms of Development 49 $3-11$.

Matzuk MM, Kumar TR, Vassalli A, Bickenbach JR, Roop DR, Jaenisch R \& Bradley A 1995 Functional analysis of activins during mammalian development. Nature 374 354-356.

Mtango NR, Varisanga MD, Dong YJ, Rajamahendran R \& Suzuki T 2003 Growth factors and growth hormone enhance in vitro embryo production and post-thaw survival of vitrified bovine blastocysts. Theriogenology 59 1393-1402.

Nie GY, Li Y, Batten L, Griffiths B, Wang J, Findlay JK \& Salamonsen LA 2000 Uterine expression of alternatively spliced mRNAs of mouse splicing factor SC35 during early pregnancy. Molecular Human Reproduction 6 1131-1139.

Orimo T, Taga M, Matsui H \& Minaguchi H 1996 The effect of activin-A on the development of mouse preimplantation embryos in vitro. Journal of Assisted Reproduction and Genetics 13 669-674.

Otani T, Minami S, Kokawa K, Shikone T, Yamoto M \& Nakano R 1998 Immunohistochemical localization of activin $A$ in human endometrial tissues during the menstrual cycle and in early pregnancy. Obstetrics and Gynecology 91 685-692.

Petraglia F, Vaughan J \& Vale W 1989 Inhibin and activin modulate the release of gonadotropin-releasing hormone, human chorionic gonadotropin, and progesterone from cultured human placental cells. PNAS 86 5114-5117.

Petraglia F, Florio P, Luisi S, Gallo R, Gadducci A, Vigano P, Di Blasio AM, Genazzani AR \& Vale W 1998 Expression and secretion of inhibin and activin in normal and neoplastic uterine tissues. High levels of serum activin A in women with endometrial and cervical carcinoma. Journal of Clinical Endocrinology and Metabolism 83 1194-1200.

Rechtman MP, Zhang J \& Salamonsen LA 1999 Effect of inhibition of matrix metalloproteinases on endometrial decidualization and implantation in mated rats. Journal of Reproduction and Fertility 117 169-177.

Roberts VJ \& Barth SL 1994 Expression of messenger ribonucleic acids encoding the inhibin/activin system during mid- and late-gestation rat embryogenesis. Endocrinology 134 914-923.

Roberts VJ, Bentley CA, Guo Q, Matzuk MM \& Woodruff TK 1996 Tissue-specific binding of radiolabeled activin $\mathrm{A}$ by activin receptors and follistatin in postimplantation rat and mouse embryos. Endocrinology 137 4201-4209.

Robertson SA \& Seamark RF 1992 Granulocyte-macrophage colony stimulating factor (GM-CSF): one of a family of epithelial cellderived cytokines in the preimplantation uterus. Reproduction, Fertility, and Development 4 435-448.

Seta M 2001 Embryo transfer after autologous endometrial coculture improves pregnancy rates. Human Cell 14 135-140.

Smith JC, Price BM, Van Nimmen K \& Huylebroeck D 1990 Identification of a potent Xenopus mesoderm-inducing factor as a homologue of activin A. Nature 345 729-731.

Song J, Oh SP, Schrewe H, Nomura M, Lei H, Okano M, Gridley T \& Li E 1999 The type II activin receptors are essential for egg cylinder growth, gastrulation, and rostral head development in mice. Developmental Biology 213 157-169.

Tessier C, Prigent-Tessier A, Bao L, Telleria CM, Ferguson-Gottschall S, Gibori GB, Gu Y, Bowen-Shauver JM, Horseman ND \& Gibori G 2003 Decidual activin: its role in the apoptotic process and its regulation by prolactin. Biology of Reproduction 68 1687-1694.

Tsai HD, Chang CC, Hsieh YY, Hsu LW, Chang SC \& Lo HY 2000 Effect of different concentrations of recombinant leukemia inhibitory factor on different development stage of mouse embryo in vitro. Journal of Assisted Reproduction and Genetics 17 352-355.

van den Eijnden-van Raaij AJ, Feijen A, Lawson KA \& Mummery CL 1992 Differential expression of inhibin subunits and follistatin, but not of activin receptor type II, during early murine embryonic development. Developmental Biology 154 356-365.

Vassalli A, Matzuk MM, Gardner HA, Lee KF \& Jaenisch R 1994 Activin/inhibin beta B subunit gene disruption leads to defects in eyelid development and female reproduction. Genes \& Development 8 414-427.

Vaughan JM, Rivier J, Corrigan AZ, McClintock R, Campen CA, Jolley D, Voglmayr JK, Bardin CW, Rivier C \& Vale W 1989 Detection and purification of inhibin using antisera generated against synthetic peptide fragments. Methods in Enzymology 168 588-617.

Verschueren K, Dewulf N, Goumans MJ, Lonnoy O, Feijen A, Grimsby S, Vandi Spiegle K, ten Dijke P, Moren A, Vanscheeuwijck P, et al. 1995 Expression of type I and type IB receptors for activin in midgestation mouse embryos suggests distinct functions in organogenesis. Mechanisms of Development 52 109-123.

Yoshioka K, Suzuki C \& Iwamura S 1998 Activin A and follistatin regulate developmental competence of in vitro-produced bovine embryos. Biology of Reproduction 59 1017-1022.

Received 19 May 2006

First decision 28 June 2006

Revised manuscript received 4 July 2006

Accepted 9 August 2006 